\title{
Habit Protokol Kesehatan Keluar Masuk Rumah dalam Pencegahan Covid-19 oleh Masyarakat di Kelurahan Kenali Besar Kota Jambi
}

\author{
Armina $^{1}$, Dwi Kartika Pebrianti ${ }^{2}$ \\ ${ }^{1,2}$ Program Studi S1 Keperawatan, STIKes Baiturrahim Jambi \\ Email: arminanurwa86@gmail.com
}

Submitted : 16/03/2021

Accepted: 08/01/2022

Published: 28/01/2022

\begin{abstract}
The increase in Covid-19 cases has now reached tens of millions of cases worldwide and in Indonesia itself in early February there has been an increase in cases to more than 270 thousand cases. The process of covid-19 transmission is quite fast, namely transmission between humans so that this pandemic cannot end because humans will always have mobility from one place to another. The protocol for oneself also needs to be built in a habit, especially when going in and out of the house because of having to work or have an urgent need. Community service activities are carried out in the form of health protocol education in and out of prevention of Covid-19 and provision of covid-19 prevention equipment which is carried out in RT 30 of KenaliBesar Village to 10 residents within the period of implementation from October to February 2021. Service activities include education, demonstrations, giving booklets, giving masks, handsanitizers and tissues. Before education, residents had high knowledge and habits as well as after education. However, some understanding and increasing better habits need to be realized by residents so that family members can avoid Covid19. Residents are quite enthusiastic and will try to familiarize themselves with health protocols in and out of the house so that family members can avoid Covid19.
\end{abstract}

Keywords: covid19, family, protocol in and out of the house

\begin{abstract}
Abstrak
Peningkatan kasus covid-19 saat ini sudah mencapai belasan juta kasus di seluruh dunia dan di Indonesia sendiri pada awal Februari 2021 telah terjadi peningkatan kasus hingga lebih dari 270 ribu kasus. Proses penularan covid-19 yang cukup cepat yaitu penularan antar manusia sehingga pandemic ini belum bias berakhir karena manusia akan selalu ada mobilitas dari satu tempat ketempat lain. Protokol untuk diri sendiri juga perlu dibangun kebiasaan terutama ketika keluar masuk rumah oleh karena harus bekerja atau ada kebutuhan mendesak. Kegiatan pengabdian masyarakat dilakukan dalam bentuk edukasi protokol kesehatan keluar masuk pencegahan covid-19 dan pemberian peralatan pencegahan covid-19 yang dilaksanakan di RT 30 Kelurahan Kenali Besar pada 10 warga dalam rentang waktu pelaksanaan bulan Oktober hingga Februari 2021. Kegiatan pengabdian berupa edukasi, demonstrasi, pemberian booklet, pemberian masker, hand sanitizer dan tisu. Sebelum edukasi warga telah memiliki pengetahuan dan habit yang tinggi begitu juga setelah edukasi. Namun beberapa pemahaman dan peningkatan habit yang lebih baik perlu disadari oleh warga agar anggota keluarga terhindar dari Covid19. Warga cukup antusias dan akan berupaya dalam membiasakan protokol kesehatan keluar masuk rumah agar anggota keluarga terhindar dari Covid19.
\end{abstract}

Kata Kunci: covid19, keluarga, protokol keluar masuk rumah

\section{PENDAHULUAN}

Sars Cov-2 dapat menyebabkan Corona Virus Disease-19 saat ini telah menyerang berbagai lapisan masyarakat, orang dewasa, orangtua hingga ank-anak. Golongan virus ini juga termasuk kelompok penyebab Severe Acute Respiratory Syndrome (SARS) dan virus penyebab
Middle-East Respiratory Syndrome (MERS) namun memiliki pola kecepatan penyebaran yang sangat cepat dibandingkan kedua penyakit tersebut.

Berdasarkan data satuan tugas penanganan Covid 19 Indonesia, jumlah kasus terkonfirmasi positif hingga tanggal 29 September 2020 yaitu 282.724 orang 
dengan jumlah kematian mencapai 10.601 jiwa. Kalangan masyarakat yang rentan menderita penyakit Covid-19 ini adalah lanjut usia terutama yang memiliki penyakit komorbid. Namun hingga saat ini, Coronavirus jenis ini menyebar sangat cepat sehingga kasus kematian akibat Covid-19 ini juga cukup banyak dialami oleh kalangan usia dibawah lanjut usia terutama dengan penyakit komorbid.

Pencegahan Covid-19 yang dianjurkan oleh Pemerintah Indonesia saat ini terdapat 5 poin utama yaitu memakai masker, menjaga jarak (physicaldistancing), menghindari kerumunan, tetap berada di rumah saja kecuali ada keperluan mendesak dan mencuci tangan. Oleh karena adanya tuntutan pemenuhan kebutuhan sehari-hari, sehingga banyak anggota keluarga yang mengharuskan keluar rumah untuk bekerja dan dianjurkan untuk tetap mematuhi 5 prinsip pencegahan utama tersebut diatas. Namun sayangnya himbauan pencegahan tersebut belum mampu menekan proses penyebaran penyakit Covid-19 ini.

Pemerintah telah banyak membuat panduan protokol kesehatan di berbagai tempat meliputi protokol Covid-19 di tempat-tempat umum maupun ketika kembali ke rumah. Adapun poin penting protokol kesehatan keluar masuk rumah menurut Badan Nasional Penanggulangan Bencana (BNPB) dan Kementerian Kesehatan RI yaitu melepas sepat sebelum masuk rumah, jangan sentuh apapun sebelum mencucitangan, melepas pakaian, masker kain dan segera masukkan ke dalam keranjang atau mesin cuci, meletakkan barang bawaan seperti tas, dompet, kunci, buku dalam suatu kotak lalu disemprot desinfektan, segera mandi, jika tidak langsung mandi maka cuci semua area kulit yang terkena paparan dari luar, serta bersihkan kacamata dan handphone dengan desinfektan dan tisu. Setelah melakukan hal tersebut, baru diperbolehkan menyapa dan berkumpul dengan anggota keluarga. Namun tentunya pencegahan ini memerlukan kebiasaan bersama anggota keluarga lainnya.

Berdasarkan data kasus Covid-19 hingga tanggal 27 September 2020 mencapai 446 kasus positif dengan jumlah kematian 6 jiwa di Provinsi jambi sedangkan di Kota Jambi kasus terkonfirmasi positif covid-19 hingga 179 kasus dengan kematian 2 jiwa. Jumlah kasus positif terbanyak di Kota Jambi terdapat di Kecamatan Alam Barajo yaitu 37 kasus dan paling tinggi di Kelurahan Kenali Besar yaitu14 kasus dengan 1 jiwa yang meninggal. Oleh karena itu, tim pengabdian masyarakat akan melakukan edukasi mengenai protokol keluar masuk rumah demi mencegah Covid-19 ke dalam anggota keluarga melalui daring dan pemberian perangkat pencegahan covid-19.

Tim pengabdian berencana melakukan pengabdian masyarakat terkait edukasi protokol covid-19 berupa keluar masuk rumah. Permasalahan mitra yaitu :

1) Adanya tuntutan pemenuhan kebutuhan keluarga sehingga kepala keluarga atau orang-orang di dalam rumah terpaksa keluar rumah untuk bekerja dan beresiko membawa virus Covid-19 kerumah

2) Lokasi mitra dekat dengan jalur perlintasan kendaraan antar Provinsi (yaitu Provinsi Sumatera Selatan) sehingga orang-orang yang datang melalui jalur tersebut melewati lokasi mitra dan beresiko mampir dan membawa virus Covid-19.

\section{TARGET DAN LUARAN}

Sasaran dari mitra pengabdian ini adalah warga RT Kenali Besar Kota Jambi sebanyak 10 warga. Luaran yang diharapkan dari kegiatan pengabdian yang dilaksanakan berupa peningkatan pengetahuan, penerapan IPTEK (praktik protokol kesehatan keluar masuk rumah, etika batuk dan bersin, cuci tangan) dimasyarakat serta publikasi di jurnal 
abdimas nasional terdaftar ISSN atau terakreditasi.

\section{METODE PELAKSANAAN}

Waktu pelaksanaan pengabdian masyarakat ini dilakukan dalam rentang waktu Januri- Februari 2021. Adapun tahapan pelaksanaan kegiatan mulai dari edukasi mengenai Covid19, pencegahan Covid19 pada anggota keluarga dengan penerapan protokol keluar masuk rumah demonstrasi protokol keluar masuk rumah, cuci tangan dan etika batuk atau bersin. Adapun kegiatan pengabdian ini dilaksanakan ke rumah-rumah dikarenakan Indonesia masih dalam situasi pandemi COVID-19 yang mengharuskan memakai protkol kesehatan dan jaga jarak dan menghindari kerumunan.

\section{HASIL DAN PEMBAHASAN}

Kegiatan edukasi dalam rangka upaya membentuk habit atau kebiasaan protokol keluar masuk rumah oleh warga terlaksana dengan lancer serta mendapat sambutan yang baik oleh warga dan ketua RT.

Tabel 1.Distribusi frekuensi pengetahuan warga sebelum dan sesudah

\begin{tabular}{cccccc}
\hline N & KategoriPenget & \multicolumn{2}{c}{ Pretes } & \multicolumn{2}{c}{ Postes } \\
\cline { 3 - 6 } a & ahuan & n & $\mathbf{f}$ & $\mathbf{n}$ & $\mathbf{f}$ \\
\hline 1 & Rendah & 2 & 20 & 1 & 10 \\
& & & $\%$ & & $\%$ \\
\hline 2 & Tinggi & 8 & 80 & 9 & 90 \\
& & & $\%$ & & $\%$ \\
\hline & \multirow{2}{*}{ Total } & 1 & 100 & 1 & 100 \\
& & 0 & $\%$ & 0 & $\%$ \\
\hline
\end{tabular}

Tabel 4.2 Distribusi frekuensi habit warga terhadap protocol masuk keluar rumah sebelum dan sesudah

\begin{tabular}{llcccc}
\hline N & $\begin{array}{c}\text { KategoriHabit } \\
\text { o }\end{array}$ & \multicolumn{2}{c}{ Pretes } & \multicolumn{2}{c}{ Postes } \\
\cline { 3 - 6 } & $\begin{array}{c}\text { MasukKeluarR } \\
\text { umah }\end{array}$ & $\mathbf{n}$ & $\mathbf{f}$ & $\mathbf{n}$ & $\mathbf{f}$ \\
\hline 1 & Rendah & 2 & 20 & 1 & 10 \\
& & & $\%$ & & $\%$ \\
\hline 2 & Tinggi & 8 & 80 & 9 & 90 \\
& & & $\%$ & & $\%$ \\
\hline
\end{tabular}

\begin{tabular}{ccccl}
\hline Total & 1 & 100 & 1 & 100 \\
& 0 & $\%$ & 0 & $\%$ \\
\hline
\end{tabular}

Berdasarkan hasil pengabdian masyarakat kepada 10 warga RT 30 Kenali Besar Kota Jambi terlihat perbedaan peningkatan warga mengenai Covid19 serta protocol pencegahan Covid19 keluar masuk rumah. Ketika demonstrasi protocol masuk keluar rumah serta cara etika batuk terlihat warga mengiyakan dan bias mengulang kembali yang diajarkan oleh tim pengabdian. Terlihat berdasarkan tabel 4.1 dan 4.2 bahwa pengetahuan dan habit warga sudah terlihat tinggi.

Pengetahuan dan habit warga dalam penerapan protocol kesehatan secara umum yang sering digaungkan berdampak pada habit keluar masuk rumah sesuai tabel 4.2 hal ini dikarenakan warga telah banyak menerima informasi mengenai pencegahan Covid19 dan mulai membiasakan diri dengan pandemi Covid19 yang belum hilang hingga saat ini.

Pengetahuan warga kategori tinggi sebelum edukasi karena lebih dari $70 \%$ menjawab evaluasi kuesioner mengetahui mengenai Covid19 beserta pencegahannya. Kuesioner pengetahuan yang banyak salah dijawab cukup bervariasi walaupun $70 \%$ benar dari 10 pertanyaan adalah mengenai virus Covid19 dianggap tidak ada, jika kondisi sehat tidak akan diserang Covid19, Covid19 menular melalui udara, covid19 dapat menular jika ada orang yang bersin, dan tidak akan menular tidak mencuci tangan dan menyentuh wajah. Tim pengabdian berasumsi bahwa pemahaman lebih detail mengenai Covid 19 harus dijelaskan agar warga lebih paham dan menyadari bahaya Covid19 dikarenakan penularan Covid19 yang cukup menularan manusia. Hal ini sesuai pernyataan UNICEF (2020) bahwa COVID-19 dapat menyebar dari orang ke orang melalui percikan-percikan dari hidung atau mulut yang biasa disebut droplet. Droplet dapat menyebar keluar saat orang yang terjangkit 
COVID-19 batuk atau mengeluarkan napas. Droplet kemudian jatuh dan menempel dipermukaan benda di sekitar seperti: meja, pintu, kursi, kaca dan sebagainya. Jika Orang sehat menyentuh benda atau permukaan tersebut, lalu menyentuh mata, hidung atau mulutnya, maka orang tersebutdapatterjangkit COVID-19. Penularan COVID-19 juga dapat terjadi jika orang secara tidak sadar menghirup percikan yang keluar dari batuk atau napas orang yang terjangkit COVID-19.

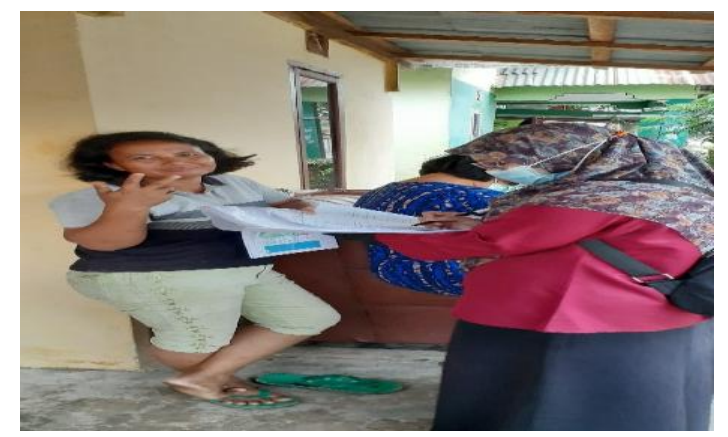

Gambar 1. Bersama warga sebelum edukasi (mengisi kuesioner pengetahuan dan kuesioner perilaku habit protocol keluar masuk rumah)

Tim pengabdian lalu memberi edukasi menggunakan booklet dan demonstrasi pencegahan Covid 19. Dari 10 warga yang diedukasi, 9 warga mengakui bahwa mereka perlu lebih meningkatkan pencegahan covid19 karena pandemic belum berakhir. Tim pengabdian menegaskan mengenai etika batuk atau bersin karena Covid19 yang sifatnya mudah menular melalui droplet dan udara agar menutup mulut dan hidung ketika betika batuk atau bersin menggunakan tisu atau lengan baju bagian dalam dan tidak menggunakan telapak tangan ketika bersin atau hanya sekedar menjauhi orang lain ketika bersin. Oleh karena itu, tim pengabdian memberikan perlengkapan pencegahan covid 19 berupa masker, tisu dan hand sanitizer.

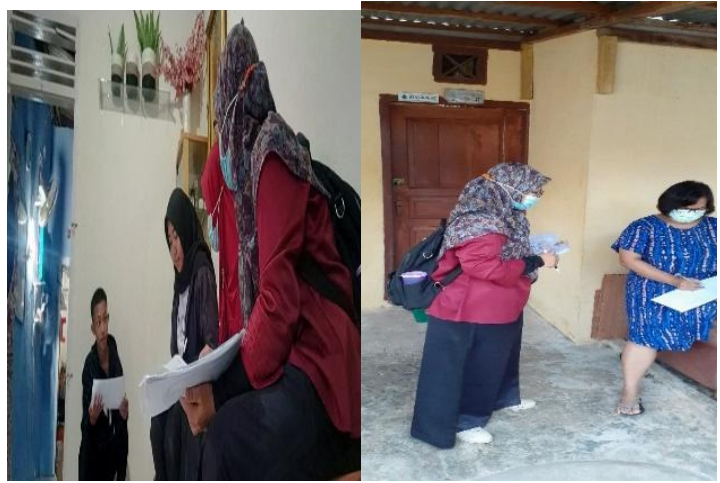

Gambar 2. Bersama Warga Setelah Edukasi (Mengisi Kuesioner Pengetahuan)

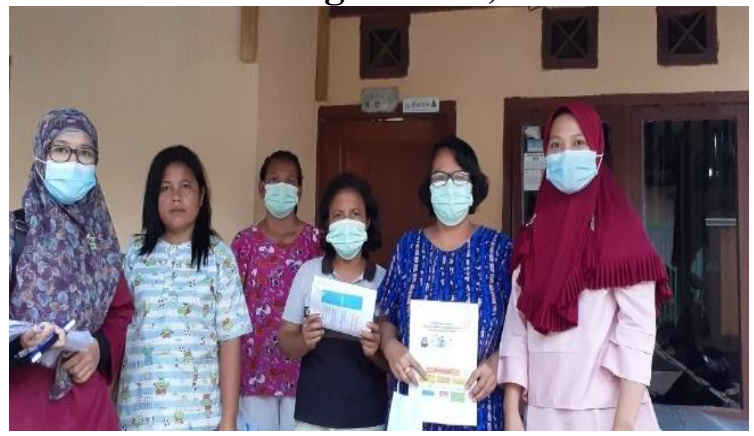

Gambar 3. Foto Bersama Paska Mengisi Kuesioner dan Pemberian Masker, Hand Sanitizer dan Tisu

Sehari setelah edukasi, tim pengadian mengevaluasi habit 10 warga tersebut dan terlihat sesuai tabel 4.2 dalam menjawab kuesioner habit yang menunjukkan terjadi peningkatan habit warga dalam mencegah covid19 (lebih dari $70 \%$ dari 19 pertanyaan). Tim pengabdian mengakui bahwa evaluasi habit warga yang hanya sehari belum menunjukkan perubahan perubahan perilaku signifikan. Namun setidaknya evaluasi sehari tersebut sebagai pengingat dan karena barumenerima edukasi kesehatan.

Menurut teori Dr. Maxwell Maltz (Maltz, 2015) bahwa membentuk kebiasaan baru adalah 21 hari, namun menurut Philippa Lally dari Universitas London (Habibi, 2020) bahwa rata-rata 66 hari untuk mengubah kebiasaan baru. Berdasarkan teori tersebut, habit baru dalam masa Covid19 ini membutuhkan waktu dalam rentang waktu tersebut agar dapat 
menekan angka kasus Covid 19. Selain itu, perilaku kesehatan akan lebih langgeng jika dibekali dengan pemahaman atau pengetahuan dari individu. Tim pengabdian berharap 10 warga ini dapat mempertahankan habit yang sudah dilakukan dengan baik dan dapat menyebarkan informasi ini ke tetangga sekitar mereka.

\section{KESIMPULAN}

Kegiatan pengabdian masyarakat berupa edukasi melalui pendidikan kesehatan dan demonstrasi cuci tangan, pakai masker dan etika batuk terkait protocol keluar masuk rumah pencegahan Covid19 pada warga telah berjalan lancer walau harus dating kerumah anak dengan protocol kesehatan dan sehari setelah peserta diberi edukasi kesehatan, warga terlihat terjadi peningkatan habit yang lebih baik.

\section{SARAN}

Melalui kegiatan pengabdian masyarakat ke rumah - rumah ini berupa kegiatan edukasi tentang protokol keluar masuk rumah pencegahan Covid19 pada warga diharapkan dapat menambah pengetahuan dan pemahaman, serta mau menerapkan di setiap hari agar terbentuk kebiasaan (habit) yang sehat.

\section{UCAPAN TERIMAKASIH}

Ucapan terimakasih kami sampaikan kepada STIKes Baiturrahim Jambi yang mendanani kegiatan pengabdian masyarakat ini, Ketua PPPM yang memfasilitasi kegiatan pengabdian masyarakat, kepada ketua RT 30 Kenali Besar, warga RT 30 Kenali Besar, dan mahasiswa yang .berpartisipasi dalam pengabdian ini.

\section{DAFTAR PUSTAKA}

Habibi, A. 2020. Normal baru pasca Covid19. Adalah Buletin Hukum\&Keadilan, 4 (1), 197-204. ISSN 23384638.

Keputusan Menteri Kesehatan Republik Indonesia Nomor HK. 01.07/Menkes/382/2020 tentang Protokol Kesehatan bagi masyarakat di tempat dan fasilitas umum dalam rangka pencegahan pengendalian corona virus disease 2019 (Covid-19)

Maltz, M. 2015. Psycho-Cybernetics: Updated and Expanded tarcherPerigee.

Diaksesdarihttps://www.amazon.com/ Pscho-Cybernetics-Updated-

Expanded-MaxwellMaltz/dp/0399176136

$\begin{array}{lll}\text { Tim } & \text { PKRS } & \text { RSST. }\end{array}$

https://rsupsoeradji.id/protokolmasuk-rumah-setelah-bepergian-dimasa-pandemi-covid-19/

UNICEF. (2020). Pesan dan Kegiatan Utama Pencegahan dan Pengendalian COVID-19 di Sekolah. UNICEF. https: // www.who.int/ docs/defaultsource/searo/indonesia/covid19/pesan -dan-kegiatan-utama- pencegahandan-pengendalian- covid- 19- disekolah--- indonesian--march2020.pdf?sfvrsn $=\quad$ 5cdfea17_2 